\title{
The GRP-MILF Peace Talks: Quo Vadis?
}

Rizal G. Buendia

\section{Introduction and Background}

The conclusion of the 1996 Final Peace Agreement (FPA) ${ }^{1}$ between the Government of the Philippines (GRP) and the Moro National Liberation Front (MNLF) did not terminate the Muslim secessionist movement in the island of Mindanao and Sulu archipelago, in southern Philippines. Nur Misuari's (Founder and Chairman of the MNLF) assumption as Regional Governor of the Autonomous Region in Muslim Mindanao (ARMM) ${ }^{2}$ and as Chairman of the Southern Philippines Council for Peace and Development (SPCPD) ${ }^{3}$ for five (5) years (19962001) has not brought about the promised peace and development in Mindanao, Sulu, and Palawan.

The ignominious failure of Misuari to effectively wield governmental powers to attain Muslims' quest for lasting peace and sustained development led to his ouster not only as ARMM Governor and SPCPD Chairman but also as MNLF Chairman. Misuari's expulsion from government was followed by his incarceration and is currently facing trial for charges of sedition $^{4}$ and corruption. 5

The MNLF, the revolutionary organisation that Misuari led for 30 years both in war and peace, is now under a new leadership. Led by the "Council of 15", it "retired" Misuari and disgracefully rendered him powerless by euphemistically naming him as "Chairman Emeritus". Through a resolution it issued on 29 April 2001, Misuari was declared as “incompetent” to remain as MNLF's Chairman. The Council later proclaimed itself as the legitimate Central Committee of the $\mathrm{MNLF}^{7}$ which was eventually recognized both by the

Rizal G. Buendia is Associate Professor, Political Science Department, De La Salle University-Manila, Philippines. 
Organisation of Islamic Conference (OIC) and the Philippine government. Support for the new MNLF leadership was reiterated in the OIC's $10^{\text {th }}$ Summit Meeting held in Putrajaya, Malaysia, on 15 October 2003, claiming it to be the sole "representative of Muslim community in the Philippines". 8

Despite the OIC's and the government's acknowledgement of MNLF and the ARMM as the Muslims' organisational expression and spokesperson in the Philippines, they nevertheless recognise that the Muslims' quest for political autonomy and self-governance has not been fully satisfied. The ARMM, even under the new breed of MNLF leadership, has yet to realise its mandated goals not only in alleviating Muslim socio-economic conditions but also in securing, preserving, and protecting the integrity of their identity, culture, and religion.

Moreover, the uncertainty and nebulousness of the autonomy package offered by the government failed to fully extinguish the cause of Muslim secessionist movement in the Philippines. Although the MNLF had relinquished its armed separatist struggle since $1976^{9}$ before finally deciding to be part of the government in 1996, the Muslim independence movement has continued; this time, spearheaded by the Moro Islamic Liberation Front (MILF).

The MILF, a breakaway faction of the MNLF in $1977^{10}$ chaired by Salamat Hashim, until his death on 13 July 2003, had been sidelined by the Philippine government from the 1996 peace talks. Faced with legal and technical constraints to forge a separate peace agreement with the MILF, the government had no other recourse but to conclude the GRPMNLF FPA before embarking on a new round of peace talks with the former. ${ }^{11}$ Similarly, the MILF adopted a "wait-and-see" attitude while the GRP-MNLF talks were in progress. ${ }^{12}$ Hence, GRP-MILF peace process only began in 1997 though informal peace overtures started a year earlier. 
As a party outside of the GRP-MNLF peace process, the MILF was able to focus its efforts in expanding and consolidating its military strength while awaiting the results of the FPA. In what seemed to be a minuscule armed-force when it severed from MNLF, the MILF has grown from 5,000 fighters (with some 3,000 firearms) in early 1980 s to 15,000 fighters (with more than 11,000 firearms) by the end of $1999 .{ }^{13}$ A US intelligence report estimates a stronger force, with 35,000 to 40,000 armed full-time guerrillas, ${ }^{14}$ while the MILF claims that its armed force (Bangsa Moro Islamic Armed Forces or BIAF) has about 120,000 fighters (80\% are armed) and 300,000 militiamen in late 1990s. ${ }^{15}$ Even though the Philippine military (Armed Forces of the Philippines or AFP) puts the MILF strength to be much less than what it claims - between 8,000 and 15,000 operating mainly in the provinces of Lanao del Norte, Lanao del Sur, Maguindanao, and North Cotabato - the government does not deny that rebels' ranks swelled by $14 \%$ in the first six months of 1999 and $11 \%$ in terms of firearms in the same period. Apart from its military strength, the MILF was able to establish 46 camps or “community bases", also known as "MILF territories" (13 major and 33 satellite camps) in 13 out of 15 provinces of Mindanao and Sulu archipelago.

The country has yet to cherish the fruits of the GRP-MNLF peace agreement when then President Fidel Ramos embarked on another round of exploratory talks with the MILF. Although formal peace negotiations between GRP and the MILF had started with the signing of the GRP-MILF Agreement for the General Cessation of Hostilities (AGCH) on 18 July 1997, the end of Ramos' term and assumption of President Joseph Estrada to power in June 1998 failed to yield any substantial results. In fact, armed hostilities between government and MILF forces intensified under Estrada's "All Out War" policy against the MILF in April 2000 that completely disregarded the 1998 General Framework of the Agreement of Intent $(\mathrm{GFAI})^{16}$ between GRP and MILF peace panels inked under his own administration. 
Six years after the signing of the AGCH, and now under President Gloria MacapagalArroyo, the GRP-MILF negotiations, though resumed in 2001 through the signing of the General Framework for the Resumption of Peace in Kuala Lumpur, Malaysia, have yet to be concluded. Generally, the peace talks have been highly volatile, tenuous, insubstantial, limited to ceasefire agreements (oftentimes breached rather than respected), and presently run longer than the 1992-1996 GRP-MNLF talks.

Against such backdrop, this chapter intends to analyse the dynamics of the ongoing GRP-MILF peace talks in relation to the interest of the state to safeguard and protect its territorial integrity on the one hand, and the continuing quest of Muslims to "selfdetermination" on the other hand.

\section{Peace and War in 2003}

GRP-MILF negotiations in the whole of 2003 focussed on resuscitating the stalled peace talks of May 2002, known as the "fourth round of formal peace talks". Except for the first round, which sealed the Tripoli Agreement of Peace of 2001 that defined three major agenda items - security, rehabilitation, and ancestral domain, ${ }^{17}$ the second and third rounds plainly centred on implementing guidelines on ceasefire agreements. ${ }^{18}$ The fourth round of talks produced two agreements. One was in the form of a Joint Communiqué that provides an "ad hoc joint action group" of GRP and MILF forces to isolate and interdict "criminal syndicates and kidnap-for-ransom groups including so-called 'Lost Commands' operating in Mindanao." The second was an agreement on "Implementing Guidelines on the Humanitarian, Rehabilitation and Development Aspects of the GRP-MILF Tripoli Agreement on Peace of 2001”. However, the Agreements, signed respectively on 6 and 7 May 2002 in Cyberjaya and Putrajaya both in Malaysia, became controversial as they were done through backchannel negotiations - without the knowledge of the GRP's negotiating panel. The 
President's Adviser on Special Concerns, Norberto Gonzales, signed the documents on behalf of the GRP rather than the official negotiating panel's chief, Jesus Dureza. President Arroyo, nonetheless, defended the process and upheld the validity of the Agreements as "confidencebuilding measures" that will prepare both parties for more comprehensive peace talks in the future. $^{19}$

Unfortunately, a month before the start of another round of formal peace talks in early March 2003, a military campaign was launched in the Muslim village of Buliok ${ }^{20}$ in the towns of Pagalungan and Pikit off the Ligawasan Marsh in the province of North Cotabato on 11 February 2003 - the Holy Feast of the Sacrifice (Eid-ul Adha, end of the Hajj or holy pilgrimage) - one of the biggest celebrations in Islam. This has angered the MILF and other Muslims and has given a religious colour to the war that is fuelled by poverty and injustice. The fighting, which lasted nearly a week, came after Manila accused the MILF of harbouring members of the so-called "Pentagon Gang", a kidnap-for-ransom gang. The campaign was purportedly to go after the gang but government officials subsequently said that then MILF chair Salamat Hashim was the real target.

While Arroyo ordered a ceasefire in deference to the Islamic holiday, she instructed that offensives be resumed the next day, 12 February. Jesus Dureza, head of the government negotiating panel, tried to convene the ceasefire committee in Cotabato province but the MILF did not respond. "It was useless to convene the committee", Al Haj Murad, MILF Vice Chairman for military affairs (now Chairman of MILF) said, "because there were no guarantees that the military would stop its assault". Retaliatory attacks by MILF rebels triggered a return to full-scale fighting. Through the military eventually overran Buliok complex, MILF forces had scattered into the jungles and villages. Guerrilla attacks and ambushes against military positions and vehicles suggest the group is by no means ready to pull out of the area. 
Moreover, the MILF was blamed on the attacks against civilian communities and the bombing of civilian targets, particularly the Davao International Airport and in Kabacan marketplace in North Cotabato a week after the military attack against Buliok. Both attacks were officially denied by the MILF. The civilian casualties pointed to the brutal and ugly visage of a resumption of another "all out war" between the GRP and the MILF, reminiscent of the Estrada administration.

In the renewed attempt to bring the peace process back on track and rebuild the confidence shattered by the February conflict, exploratory talks were held on 27 and 28 March 2003 in Kuala Lumpur between the GRP and MILF panels. The agreement came in the form of a Joint Statement that provides among others, the following:

- $\quad$ Reaffirmation of commitment to achieve a comprehensive, just and lasting political settlement on the conflict in Mindanao and resolve to undertake appropriate steps to pave the way for the resumption of the formal GRP-MILF peace negotiations;

- Effective implementation on the ground of all past and existing GRP-MILF agreements;

- Exercise mutual restraint to minimize, if not put an end to, violence in Mindanao;

- Normalize the situation and facilitate the early return of evacuees to their places of origin and allow rehabilitation to proceed;

- $\quad$ Activation of the Bangsamoro Development Agency; ${ }^{21}$

- Direct their respective technical committees to work on implementing the guidelines of the 6 May 2002 Joint Communiqué to ensure that the peace process is not adversely affected by the presence of criminal groups in Mindanao; 
- Improvement on the existing mechanism for monitoring of the cessation of hostilities including the composition of an observer/monitoring group as provided for in the Tripoli Agreement of 2001; and

- Reaffirmation of the provision on the granting of safety and security guarantees.

The ink on the signed agreement has not dried when violence resurfaced exacting a heavy toll on civilians. Davao City (a key city in Mindanao predominated by Christians) was bombed twice, killing close to 40 people. Relying on military intelligence reports, some local government officials saw the bombing as MILF's reprisal for the military's continued occupation of Buliok. The second time around, hours after the bombing of the Davao wharf in early April, armed groups hurled grenades at three mosques that victimized civilians, an obvious retaliatory attack against Muslims. Perpetrators were obviously instigating a religious conflict.

Arroyo suspended the talks in May after a series of bombings and raids on civilians that claimed hundreds of lives and displaced hundreds of thousands in Mindanao in March and April. The government blamed the separatists for the carnage and civilian casualties, and accused the MILF as a "terrorist group" or giving refuge to "terrorists". Criminal charges in a Philippine court were later filed against MILF leaders. The rebels have consistently denied perpetrating the bombings and assaults on civilians, saying a "third force" (referring to hawkish officials in the military) was muddling the peace process.

The MILF unilaterally declared a ten-day ceasefire in late May and extended it by another ten days on 12 June. Arroyo, however, rejected the "ceasefire by instalment", urging the rebels to agree to a "permanent ceasefire" and to sign a final peace pact with the government. Presidential Adviser on the Peace Process Eduardo Ermita (now Secretary of the Department of National Defence), admitted the talks were back to "square one". ${ }^{22}$ The 
pandemonium of violence reigned in southern Mindanao despite the commitment of protagonists to collectively seek a peaceful solution to the conflict.

Through informal meetings held in Kuala Lumpur, GRP and MILF panels agreed on a "mutual cessation of hostilities" starting 19 July. Owing to Malaysia's intercession which had been brokering the peace talks since 2001, Arroyo ordered the AFP to downgrade its action "from punitive operations to active defence" against the MILF. Furthermore, she instructed the Department of the Interior and Local Government (DILG) to "lift the corresponding rewards for the arrest or capture" of MILF officials and directed the Office of the Presidential Adviser on the Peace Process (OPAPP) to issue safe conduct passes to MILF leaders engaged directly in peace talks as provided for in the GRP-MILF Agreement for Safety and Security Guarantees of $2001 .^{23}$ It was hoped these measures would remove the obstacles for the resumption of peace talks between protagonists and restore some trust and confidence built in the initial months of the Arroyo presidency.

The death of Chairman Salamat Hashim of heart failure on 13 July partly slowed down the recommencement of exploratory talks. On the other hand, Malaysian authorities facilitating the GRP-MILF talks allowed Al Haj Murad, Hashim's successor, more time to firmly consolidate his position in the Front before continuing the stalled talks.

The 5-6 September exploratory talks in Kuala Lumpur produced the following agreements:

- $\quad$ Phased redeployment of military troops in Buliok complex (Islamic Centre/Mosque). Troops to be gradually pulled out from the Buliok complex while MILF would not be allowed to use it as a base camp;

- Deployment of the Third Party Monitoring Team. The Monitoring Team would be composed of representatives from Malaysia and other OIC-member countries; 
- $\quad$ Formation of the Ad Hoc Joint Action Group (AHJAG) in compliance with the GRP-MILF Joint Communiqué of 6 May 2002 on the "interdiction and isolation of criminal syndicates and lawless elements"; and

- $\quad$ Tabled the Ancestral Domain issue as the next agenda for the formal peace talks.

Much as President Arroyo had hoped that a Final Peace Agreement be signed between the GRP and MILF on or before U.S. President Bush's visit in October, nothing of the sort teranspired. Not even Arroyo's attendance to the OIC's $10^{\text {th }}$ Summit Meeting in October in Malaysia, upon the invitation of Mahathir Mohamad, Malaysian Prime Minister and OIC chair, could accelerate the process of forging a meaningful agreement.

To date, formal peace talks have not began since the conclusion of the September agreement. One overarching issue that continues to hobble the resumption of the negotiations is the MILF's concern regarding the military's redeployment (read: withdrawal) of troops in Buliok complex (Islamic Centre). The government maintains that there had been a one-third decrease of troops in the area and the remaining soldiers have been engaged in civic works (building of core shelters, school buildings and others such) rather than in combat duties, with the nearest military detachment situated at about 200 meters from the Islamic Centre. ${ }^{24}$ Nevertheless, the MILF has consistently insisted on the complete withdrawal of AFP forces before it sits down to any scheduled peace talks. Mohaqher Iqbal, MILFs Information chief, says that "There would be no formal talks if government cannot honour its commitments", citing the September agreement. ${ }^{25}$ Likewise, Michael Mastura, one of the MILF's negotiators, declared that, "formal peace negotiations would have to wait until after the government fulfilled some previous commitments". ${ }^{26}$

While the government has signified its interest to discuss MILF's precondition prior to a new round of formal talks, it seems unlikely that a total military pull out from Buliok (the 
MILF's former base camp) will occur in the near future. Furthermore, the delayed deployment of the Third Party Monitoring Team (tasked to assess the situation on the ground in terms of compliance of both parties with previously agreed to security arrangements) in the Philippines has affected the early discussion of the more substantive issues in the GRP-MILF talks. The Team's reported arrival on the second week of January 2004, a month before the start of the campaign for the 2004 presidential and congressional elections, showed the difficulty and uncertainty of completing a respectable GRP-MILF Final Peace Agreement in the coming year.

Although a peace agreement between the GRP and MILF will not guarantee the cessation of hostilities or an assurance of lasting peace, it can momentarily provide a breathing space and create an amiable environment where stakeholders can collectively prepare the groundwork and eventually lay the structural foundations of an enduring peace and development.

\section{The State and the Bangsamoro ${ }^{27}$ National Question}

Despite the seeming resolution of the GRP-MNLF conflict through the 1996 Final Peace Agreement and institutionalisation of the Autonomous Region in Muslim Mindanao in 1989 under the 1987 Philippine Constitution, the Bangsamoro national question persists. In fact, former MNLF Chairman Misuari renewed his call for a separate Moro $^{28}$ nation-state from the Philippine republic in late 2001 as an expression of his revulsion over the failure of the government to guarantee meaningful autonomy and self-governance while he was ARMM Governor. In spite of Misuari's failure to re-mobilise the MNLF to the cause he started 30 years back, the issue of Muslim separatism has not completely died down.

Notwithstanding the ideological differences of the MNLF and MILF — the former as more secular while the latter being more Islamic - they see themselves as "one people" 
bound collectively on the basis of a common ancestry, history, society, institutions, territory, and more importantly, religion. As the minority people in a predominantly Christian nation, they perceive themselves as the marginalized, persecuted, and powerless people both politically and economically. Regardless of organisational affiliation, independence remains the underlying essence of political autonomy for Muslim socio-politico movements.

Given a common conception of identity, purpose, and future, they feel the need to separate themselves from those against whom they have been judged unfavourably and who reduced them to a state of poverty and underdevelopment; and subjected them to injustice and prejudice. Thus, they must proclaim themselves as "a new people", a Bangsamoro. The consciousness of being one people distinct from the neighbouring peoples, the Filipinos, is articulated and self-ascribed. They have renounced their identity as Muslim-Filipino and declared themselves "Moro", which denotes the descendant of "unsubjugated" and "uncolonized" peoples; and claimed their homeland as the Bangsa Moro that has been "unjustifiably annexed by the Philippine state". What appeared to be the state's continuing prejudices against the Muslims had found Islamic expression through the MILF, rather than secular as in the case of the MNLF.

The late MILF Chairman Hashim believed that what the GRP-MNLF FPA resolved was the government's problem and not the Bangsamoro problem, "the agreement never touched the core of the Bangsamoro problem which is the illegal and immoral usurpation of their (referring to the Moros) ancestral homeland and legitimate rights to freedom and selfdetermination". ${ }^{29}$ In an interview with the Crescent International in 1999, Hashim argued that MILF "would never agree to any solution other than the full independence of the Bangsamoro homeland... the establishment of an Islamic State." ${ }^{30}$

The ideals of MILF did not die with Hashim. His successor, Al Haj Murad, delivered a message on the occasion of the fasting month of Ramadhan in November, in which he 
expressed that "there can be no genuine peace and development unless the right of the Bangsamoro people to self-determination is adequately addressed." 31 The right to "selfdetermination" is nothing less than an assertion of political independence from the Philippine state.

While the MILF is currently engaged in peace negotiations as the only "peaceful, civilised, and democratic way of solving the Bangsamoro problem", 32 it repeatedly emphasizes that independence is the main agenda and framework for the formal talks. "There is no point to proceed if the negotiations will not lead to independence", declared the MILF negotiators. The sustained effort towards gathering popular support for a UN- and OICsupervised referendum, following the East Timor's (now Timor-Leste) case, is a move to achieve independence using the institution and process of democracy. For the MILF, the conduct of a referendum is one of the options or mechanisms that it can utilise outside of the peace talks. It is the exercise of the "plebiscitary right to secede". 33

On the part of the Philippine government, the defence and preservation of its territorial integrity at all costs remains its primordial interest. Gaining the support of the OIC, the UN, and ASEAN (Association of Southeast Asian Nations), the Philippines has maintained that attempts that will transfigure the country's political structure and geographical jurisdiction will have to be done within the constitutional framework and processes of the country. Hence, MILF's ultimate agenda to secede, as what the MNLF began in 1971, is a non-negotiable subject in the GRP-MILF peace talks. In other words, secession cannot be negotiated.

Much to the desire of the MILF to cite the case of East Timor as a model en route to independence, the historical circumstances of Mindanao and East Timor are different. The latter is a clear case of de-colonisation where the principle of self-determination applies 
whereas the former has yet to prove the basis of its peoplehood before the international community aside from meeting the stringent conditions of nationhood.

Unlike Mindanao and the Sulu archipelago, East Timor was never part of Indonesia when Sukarno declared independence in 1945. It was a former colony of Portugal and not of the Dutch which colonised the entirety of Indonesia for centuries. In 1975, the new left-wing Portuguese government relinquished all of its colonies. East Timor then enjoyed just a few days of independence, before Indonesia annexed it as their $27^{\text {th }}$ province in December 1975. The presence of "communist-inspired" independence movement, which may threaten the security of Indonesia and of the region was one of the reasons proffered by Suharto in the brutal invasion of East Timor. The UN and the international community never recognised Indonesia's forceful takeover of East Timor.

Although the U.S., Australia, and some Western powers then supported Suharto for serving their strategic security interest in the region, they later rallied behind the independence movement of East Timor when the Cold War ended. Under the new global democratic environment, East Timor's quest to self-determination became one of the major concerns of the UN. Several high-level negotiations were held between Indonesia and Portugal under the good offices of the UN. In June 1999, Bacharuddin Jusuf Habibie, then President of Indonesia announced that a referendum would be held in East Timor — offering independence or "wide-ranging autonomy" within Indonesia. In the UN-supervised referendum held in August 1999, about 80 percent of the people voted for independence. The results were recognised by Indonesia and finally completed the process of de-colonisation and self-determination.

MILF's attempt to cut a replica out of the East Timor's experience is fraught with difficulties. Among the key concerns are as follows: One, the limited international support for secession. The OIC, UN, and even ASEAN maintain their support for the Philippines' 
sovereign right to uphold the sanctity of its territorial boundaries. Further, they endorse that substantive political autonomy under the Philippines' constitution could answer the Bangsamoro legitimate problems. Notably, some pressures are applied on the MILF, especially by the OIC, which has sustained the Moro cause through the years, to agree on the negotiated settlement with the GRP. President Muammar Al-Qadhafi of Libya, on the occasion of the opening of the GRP-MILF first round of formal talks on 20 June 2001 in Tripoli, said that Muslims in the Philippines "can achieve peace and development only within the framework of the Republic of the Philippines and its constitutional guarantee of justice, equality and mutual respect, of tolerance, of freedom from oppression, and freedom from discrimination". 34

Second, the MILF's inability to gain official recognition from the OIC as the sole representative of Muslims in the Philippines in the 2003 OIC Summit meeting in Malaysia seems to augur badly for its acceptability. The OIC has continued to acknowledge the MNLF, whose leaders are now key officials of the ARMM. And third, the ability of the GRP to project the MILF as a terrorist organisation or haven for terrorist elements, though vehemently and repeatedly denied by the latter, has stained the revolutionary image of the MILF.

The weak position of the MILF to negotiate with the GRP on the "self-determination" agenda does not mean that the concept of a Bangsa Moro is entirely flawed or problematic. Nor should the government ignore the causes of Bangsamoro rebellion. The demonstrated capacity of the MILF to mobilise a huge armed force is better seen as the key symptom of the Philippine government's predicament in respect to its Muslim minority.

The Muslim separatist movement in the Philippines is fundamentally rooted in the following causes, among others: One is the low degree of political autonomy which would enable Muslims to protect, safeguard, and defend their culture, identity, language, ways-of- 
life, and religion. Meaningful political autonomy becomes imperative to improve the quality of opportunity as well as individual autonomy of the members of the Muslim minorities. Second is the inability of the state to adequately meet the basic socio-economic needs of the Muslim community. And third is the belief (founded or unfounded) of Muslims that they suffer from systematic discrimination or exploitation orchestrated by the state.

Under the unitary governmental structure, the so-called "autonomy" enjoyed by the ARMM has been historically an illusion. Devolution of powers manifests itself in the formal powers or administrative arrangements that are purportedly decentralised but politically controlled or influenced by the central government. In spite of the pronouncement that the government promotes "unity through diversity", policies have been centrally formulated and conceived with less regard to the heterogeneous requirements, needs, and demands of local communities especially the minority peoples. The unitary system gives the central government the political legitimacy to rule over minorities and other indigenous communities who do not feel they are part of the nation-state - in terms of culture, identity, and religion.

The failures of the ARMM and previous "autonomous regions" created in 1977 to empower and uplift the living conditions of the Muslims have made MILF less optimistic. Arroyo's proposal for a more "enhanced, expanded, and strengthened autonomy" under the draft GRP-MILF Final Peace Agreement was shrugged off. It is a "tired phrase", states Michael Mastura, one of the members of the MILF negotiating panel. ${ }^{35}$ Aquilino Pimentel, a senator from Mindanao says that the "proposed peace pact tries to deal with the effects, not the causes, of the war in Mindanao." ${ }^{36}$ He then suggests a federal structure of government to address the problem of the Bangsamoro rebellion and bring a lasting peace in Mindanao.

The centralising power of the state also failed to uplift the socio-economic and health conditions of the Muslims. After more than a quarter-of-a-century of Philippine government claims to be "developing" Muslim Mindanao, recent national statistics illustrate the sad 
reality. In virtually all measures of physical and economic well-being, the ARMM is found at or near the bottom of the national rankings. ${ }^{37}$ In government-supplied services ranging from access to prenatal care to availability of college scholarships for low-income students, ARMM ranks last while it registers the highest in terms of poverty incidence at $57 \% .^{38}$

The socio-economic conditions certainly continue to worsen as population increase naturally exerts more pressures on the capacity of traditional sources of revenue and livelihood such as the land, rivers, lakes, and seas within reach of the inadequate local technologies and crafts. As with separatist movements elsewhere, ordinary Philippine Muslims are most likely to fight for or support an armed separatist organisation when they are faced with no alternative means to survive the continuing discrimination and qualitatively improve their living conditions.

Finally, beyond economic and political grievances, the issue of separatism is one of subjective feelings, of perceptions, and of language - that Muslim minorities are being summarily discriminated and exploited by the Christian majorities. The dominant Christian community has not really obliterated the lingering anti-Muslim bias in their consciousness. The pre-conceived mutual feeling of bigotry and prejudice of Christians and Muslims has oftentimes led to conflict. And when conflicts escalate, perceptions and languages are distorted within the warring parties. The distortions are partly spontaneous and partly organized to rally the people to engage in warfare, bear the economic burdens, and face the human misery of war. Conceivably, when war breaks out, truth is its first victim.

Given the aforesaid causes of the Bangsamoro secessionist movement, uncertainties remain whether the GRP-MILF talks can satisfactorily address these concerns. Inasmuch as the negotiations have not touched on the substantive issues of the conflict, nothing is definite at this point. 
Nevertheless, in an effort to pursue the "self-determination" agenda in the talks, the MILF pushes the issue of ancestral domain. It hopes that government's recognition of the right of the Bangsamoro over their ancestral domain will eventually result to the acknowledgement of Moros' territory. "We just want a physical space where we can freely practice our religion and apply our ways-of-life. There is no need to seize power," says MILF Information Chief, Mohagher Iqbal. ${ }^{39}$

The subject of ancestral domain will be the main agenda in the next round of discussion in 2004 between the two panels. This would likely be a thorny issue and could lead to another stalemate. For instance, the government perceives the question of ancestral domain within the bounds of the 1997 law — the Indigenous Peoples' Rights Act (IPRA). IPRA seeks to recognize, protect and promote the right of indigenous peoples and cultural communities including Muslims, to claim ownership over their ancestral domain pursuant to the 1987 Constitution. On the other hand, MILF works within the notion that the right over their ancestral domain is none other than the right to their homeland - the Bangsamoro territory; believed to have been "illegally annexed by the state". It is not only about claims and rights to obtain ancestral domain titles.

Therefore, the ancestral domain rights contemplated in IPRA are hinged on the indigenous peoples' rights as stewards of the earth concept rather than on the right to selfdetermination and a correction of historical injustices. The law, further, does not depart from the Regalian Doctrine as enshrined in the 1987 Constitution. ${ }^{40}$ Nor does it divest the State of the power to determine the use of land as provided for in Section 7-c: "No Indigenous Cultural Communities/Indigenous Peoples (ICCs/IPs) will be relocated without their free and prior informed consent, nor through any means other than eminent domain”. By asserting its inherent power of eminent domain, the State in effect reserves its right to have the last word on ancestral domains. 
The MILF regards ancestral domain as the issue, which could give substance to the self-determination struggle but the government considers it a question that can be answered within the bounds of state's power and authority. The differences of framework in viewing the issue of ancestral domain could be a tough concern in the upcoming negotiations but not necessarily insurmountable.

The Bangsamoro struggle for self-determination may persist as long as the state is able to conjure up a more democratic system of governance where minorities can freely govern themselves and chart their future with less intervention from the state. Evidently, independence movements may not necessarily be violent if the avenues for dialogues and negotiations remain open.

\section{Conclusion: Prospect, Lessons and Issues}

The GRP-MILF Peace Talks in 2003 have not been too fruitful. Negotiations have been entirely focused on making ceasefire agreements more respectable and implementable as these have oftentimes been breached rather than applied. In the early part of 2004 there will be another attempt, with the participation of the OIC, to determine whether the conditions of peace are enough and institutions as well as processes in place for the GRP and MILF panels to commence the discussion on the more substantive issues behind the 26 years of MILF secessionist struggle.

However, in view of the May 2004 presidential elections the possibility of politicising the GRP-MILF peace process is not farfetched. In case a new president assumes power in June 2004, in the likes of Fernando Poe Jr., another popular movie actor ${ }^{41}$ (aside from former President Estrada) who possesses virtually no experience in public administration and whose knowledge of the Moro conflict in Mindanao is practically nil, the peace talks might be imperilled. Thus, the future of the GRP-MILF peace negotiations will practically be 
contingent on the leadership of the next Philippine president, mandated to rule until 2010 (unless abbreviated by another "People Power Uprising").

Although the GRP-MILF peace talks have not been so encouraging for the past year, the peace process provided an enriching experience not only in the better understanding of the conflict but more importantly, in appreciating the deeper issues that continue to haunt the government and the Moro movement for decades. Some of the lessons and issues that emerged from the process but have yet to be resolved are:

One, the series of peace agreements indicates the commitment of the government and the MILF to settle their political differences through the processes and mechanisms of peace. Their engagement in the peace process gives both parties the chance to discuss and settle debatable questions in a more creative and non-violent manner. Obviously, the exchange of ideas and arguments is better than exchange of bullets and bombs.

Second, if the experience of the past 32 years of armed conflict in Muslim Mindanao teaches anything, it is that the use of military strength to suppress a rebellion with a legitimate cause does not necessarily extinguish it. It simply escalates war. The "get tough" policy will have the opposite of its intended effect. It will energize the MILF and increase its popular support while undermining what is left of the 1996 Peace Agreement.

Given the current political situation in the Philippines, it is doubtful that the anxieties of the Moros would calm down. The preponderance of state power and indiscriminate use of force, victimizing non-combatants, are clearly behind the increase in violence. Human rights violations have escalated.

Third, the present law on Muslim autonomy has not been adequate to solve the problem it aims to address. Any future offers of autonomy to Muslim Mindanao have to give the Moros greater sense of economic, cultural, and political justice. It is equally important that perceptions of discrimination, separateness, prejudice, and bigotry be expunged from the 
minds and hearts of the Moros. The process of reversing outlooks and feelings of alienation demands a strategic approach of sustained and effective delivery of the package of public goods and services that would bring the government closer to the people.

Fourth, the Bangsamoro national question remains a threatening issue unless confronted squarely by the government by answering the legitimate causes of rebellion. Conflicts have underlying socio-cultural, economic and political reasons. It is almost certain that conflict breaks out if the State's response to separatism induces widespread suffering in the country or among other marginalized ethnic groups rather than alleviate the peoples' miseries through socio-economic measures. Making more people feel that the State is not their State will eventually provide separatism with new recruits. In the final analysis, it is essential that Moros be drawn within the domain of the State. Muslim minorities have to be convinced that the State really belongs to them, as well as to the Christian majority. If the State takes care of the people, the people will take care of the State.

And finally, secessionism can be dealt with more effectively through the processes, mechanisms and institutions of peace. Despite the arduous process of peace making as evidenced by the GRP-MILF peace talks, it remains the only sensible means. Secessionism can be resolved successfully only through patient and painstaking confidence-building measures and frequent dialogues that deal with the core problems mutually identified by contending parties. Definitely, there are no quick fixes, no short-cuts. Wounds that have festered for a long time cannot heal overnight. Nor can confidence be built or dialogue developed while fresh wounds are being inflicted. It is a process that requires special efforts to uphold human rights, fundamentally the right to development.

Secessionism is not merely a security problem of the State or of the region. Essentially, it is a political problem and requires a political solution. Hence, there is a need to lay emphasis on good governance, on the rule of law, on improved civil-military relations and 
on accountability for corruption and violations of human rights. These efforts would, to a large extend, facilitate the early conclusion of conflict, accelerate the process of peace, and find a respectable and honourable final peace agreement between the GRP and MILF. The courage in seeking to come to terms with the past is an essential part of the search for a new way forward.

However, given the vicissitudes of Philippine politics that tend to politicise the peace process, concluding a respectable and honourable GRP-MILF Peace Agreement in the near future remains elusive. And whenever there is a prolonged uncertainty on the future of a sealed peace agreement, fear creeps in - fear not only for the future of the negotiations but also for the future of the people.

\section{NOTES}

1. On 2 September 1996, the Philippine government and Moro National Liberation Front (MNLF) with the participation of the Organisation of Islamic Conference (OIC), signed the historic 1996 Peace Agreement also known as the Final Peace Agreement (FPA), it laid down the process and framework in achieving peace and development in Southern Philippines. (see GRP-MNLF Final Peace Agreement, 2 September 1996 for details).

2. The Autonomous Region in Muslim Mindanao (ARMM) was created on 1 August 1989 under Republic Act 6734. ARMM was initially composed of four (4) provinces, namely: Lanao del Sur; Maguindanao; Sulu; and Tawi-Tawi. The Philippine Congress passed the Republic Act 9054 on 7 February 2001. It became law on 31 March 2001 without the signature of the President, in accordance with Article VI, Section 27 (1) of the Constitution. RA 9054, which replaced RA 6734. In a plebiscite conducted on 14 August 2001, Basilan and Marawi City were added to the present ARMM. Further, RA 9054 and Executive Order 80 of 11 March 2002 dissolved the Southern Philippines Council for Peace and Development (SPCPD) and transferred all its functions, duties, and responsibilities to the new ARMM (see Republic Acts 6734 and 9054 and Executive Order 80 for details).

3. The Southern Philippines Council for Peace and Development (SPCPD) was established through Executive Order 371 issued on 2 October 1996. It acts as a transitory administrative arm under the Office of the President tasked to spur development in 14 provinces and 9 cities (as of 1996) in Mindanao and Sulu archipelago. The covered area is known as the Special Zone of Peace and 
Development (SZOPAD) SZOPAD constitutes the area where MNLF can use to campaign for autonomy. In the 2001 plebiscite, SZOPAD's coverage increased from 14 to 15 provinces and 9 to 14 cities, as local governmental units were created and capital towns converted into cities between 1996 and 2001.

4. In November 2001, while still serving as ARMM Governor and Chair of SPCPD, Misuari convened the $5^{\text {th }}$ National Bangsamoro Assembly in Parang, Sulu and resurrected his call for an independent Muslim Mindanao. He declared war against the Arroyo government and was reported to have led some armed MNLF guerrillas in an attack to an Army headquarters in Jolo, Sulu, on 19 November 2001. The event led the government to charge Misuari of sedition. He is now languishing in jail on charges of rebellion and if found guilty, he could face up to 20 years imprisonment.

5. It was also reported that Misuari pocketed funds allotted for the poverty alleviation program and his supporters spent P42 million (US\$840,000) to buy high-powered weapons. Ann Corvera, "Nur Misuari: Has the 'good warrior's' long struggle come to a disgraceful end?" Philippine Star (online) 16 January 2002, Available from: $<$ http://www.philstar.com/philstar/misua.htm>. (Accessed on 12 October 2003).

6. This was the latest and second major split in MNLF's leadership as of this writing (November 2003). The formation of the Council of 15 was engineered by the MNLF's senior leaders. Misuari's Deputy Chairman, Hatamil Hassan was elected as the Council's Chair while MNLF's Foreign Affairs Committee Chair, Parouk Hussin, was elected ARMM's new regional governor in November 2001 under the new ARMM Organic Act (RA 9054). (see Mahendra Alih Madjilon, "Attempts To Unseat Misuari”. Available from <http://mnlf.net/Attempts_to_Unseat.htm> [Accessed on 14 October 2003]).

7. Ann Bernadette Corvera, "Nur Misuari: Has the "good warrior's" long struggle come to a disgraceful end?" Philippine Star, 16 January 2002 Available from: <http://www.philstar.com/philstar/misua.htm>. (Accessed on 12 October 2003).

8. Allan Nawal and Juliet Javellana. "OIC rejects anew RP application for observer status; Gloria in KL”. Philippine Daily Inquirer, 16 October 2003.

9. On 23 December 1976, the GRP and MNLF Negotiating Panels signed the Tripoli Agreement. Under the auspices of the OIC, specifically Libya, then President Marcos caused the settlement of Muslim separatism within the framework of the Philippine Constitution. The 1976 Tripoli Agreement spiked the MNLF's separatist mission. In implementing the Agreement, Marcos created two "autonomous regions", rather than one (1) consolidated "provisional government" as contemplated under the Tripoli Agreement. Marcos effectively divided and diluted the quest of Muslims to be governed under one Muslim-defined government.

10. MILF broke ties with the MNLF and started as a reformist group in 1977, then known as New MNLF, that advocated for autonomy rather than independence. In 1984, it changed its name to Moro Islamic Liberation Front (MILF) and made Islam as its official ideology. The MILF has always placed greater emphasis on Islam than the 
MNLF, and most of its leaders are Islamic scholars from traditional aristocratic and religious backgrounds.

11. Prior to the signing of the FPA, negotiations for political settlement of the Mindanao conflict were confined with the MNLF. Considering that MNLF was signatory to the 1976 Tripoli Agreement which was the basis of the peace talks, the government was constrained to deal solely with the former. Likewise, the OIC, under whose auspices the negotiations were carried out, recognizes the MNLF as the representative organization of the Muslims in southern Philippines. Thus, formal peace talks between GRP and MILF were opened in 1997.

12. Abhoud Syed M. Lingga, "Peace Process in Mindanao", Paper presented on the roundtable discussion on "Updates on Muslims in Mindanao", 7 February 2002.

13. Richard Baker and Charles Morrison, eds., Asia Security Outlook 2000, Japan Centre for International Exchange, 2000, Tokyo, Japan, p. 130.

14. Philippine Daily Inquirer, 8 June 2000 cited in Raymund Jose Quilop, "The Uneasy and Costly Road to Peace in Mindanao", Panorama: Insights into Southeast Asian and European Affairs 3/2000. Konrad Adenauer-Stiftung, Manila.

15. "Moro National Liberation Front," Available from $<$ http://www.ict.org.il/inter_ter/orgdet.cfm?orgid=92>. (Accessed on 24 November 2003).

16. The General Framework of the Agreement of Intent (GFAI) was signed by the GRP and MILF panels on 27 August 1998 in Sultan Kudarat, Maguindanao. It provides both panels the mandate to reach a pacific settlement of conflict and pledge to implement the joint agreements/arrangements previously signed, and to protect and respect human rights.

17. The "Agreement on Peace Between the Government of the Republic of the Philippines and the Moro Islamic Liberation Front" was also known as the Tripoli Agreement on Peace of 2001. It was the first comprehensive peace agreement signed by GRP and MILF panels after negotiations were severed in April 2000 due to the "All-Out War" policy of then President Estrada. The meeting was held in Tripoli, Libya on 19-22 June 2001.

18. The second round of talks led to the signing of the Implementing Guidelines on the Security Aspect of the GRP-MILF Tripoli Agreement of Peace of 2001 on 7 August 2001 in Putrajaya, Malaysia. Known as the Ceasefire Agreement, it reactivated the Coordinating Committee in the Cessation of Hostilities $(\mathrm{CCCH})$ and created the Local Monitoring Teams (LMTs). The third round of the formal peace talks in October 2001 was supposed to tackle the issue of the rehabilitation of refugees and development of conflict-affected areas but instead agreed on the Manual of Instruction for the $\mathrm{CCCH}$ and LMTs - monitoring bodies tasked to supervise the implementation of the ceasefire. The manual, intended to harmonize the roles of $\mathrm{CCCH}$ and LMTs, was signed on 18 October 2001 at Mines Resort, Selangor, Malaysia. 
19. "Palace firm on MILF pacts; formal talks slated soon", 27 May 2002, Philippine Daily Inquirer

20. Buliok and about four adjacent villages have been the headquarters of the MILF since its Camp Abubakar stronghold fell in 2000. It was their main base, their new Abubakar. The place is referred to as the Buliok Complex by the government while MILF named it as the Buliok Islamic Centre/Mosque. It has a land area of 220,000 hectares in the borders of the provinces of Maguindanao, Sultan Kudarat, and North Cotabato.

21. The Bangsamoro Development Agency (BDA) was created in accordance with the 7 May 2002 Agreement between the MILF and GRP peace panels. The BDA, according to the Agreement, "will serve as the project implementing body of the MILF tasked to determine, lead and manage rehabilitation and development efforts in the conflictaffected areas" as well as the "power and function to receive and disburse private and government funds" provided that "pertinent Government rules and procedures would be followed in case of the latter".

22. Fe Zamora, “Back to 'Square One': Gov't reiterates permanent MILF truce before talks", Philippine Daily Inquirer, 3 July 2003.

23. "Presidential Statement on the Mutual Cessation of Hostilities". Available from: $<$ http://justpeace.net.ph/updates/statement/Presidential_Statement_Aug_20_2003.htm >. (Accessed 20 October 2003).

24. Teresita Quintos Deles, "Briefing for the Mindanao Working Group."Available from: $<$ http://www.medco.gov.ph/medcoweb/uploads/updtgrpmilf.doc>. (Accessed on 1 November 2003).

25. "Gov't, MILF still discussing pull-out of troops from Buliok". Available from: $<$ http://www.luwaran.com/grpmilfdiscusbuliok.htm>. (Accessed on 25 November 2003.

26. “Peace talks postponed”, Philippine Daily Inquirer, 28 October 2003.

27. The term "bangsa" or "bansa" is a Malay word that usually refers to nations, castes, descent groups or lines, races or estates. A.C. Milner says that the term has a Sanskrit origin (see Kerajaan: Malay Political Culture on the Eve of Colonial Rule. Association for Asian Studies, monograph no. 40. Tucson: University of Arizon Press, 1982, p. xv) The composite term "Bangsa Moro", which appears in MNLF and MILF literature as well as in a number of scholarly writings refers to the "Moro Nation". MNLF and MILF prefer to use it as one word, "Bangsamoro". For the purpose of this paper, "Bangsa Moro" shall be used to mean the "Moro Nation" as imagined by Filipino Muslims and "Bangsamoro" to the "people" who believe and practice Islam as a religion and way of life especially those inhabiting southern Mindanao and Palawan provinces and Sulu archipelago.

28. The term "Moro" was the appellation applied by the Portuguese, who seized Melaka in 1511, to all Muslim population of Southeast Asia. It was the name used by the 
Spaniards to refer to Muslim inhabitants of the Philippines, alluding to the Muslim Moorish who occupied the Iberian Peninsula and the northern coast of the African continent in 711 A.D. When the Spaniards crossed the Pacific Ocean and reached the Philippines in $16^{\text {th }}$ century, they encountered the ferocious resistance of Muslims inhabiting the Southern Sultanates of the country. This reminded them of their ancient enemy, who aside from being Islamic, were hostile like the Moors, thus called the Philippine Muslims "Moros" (see John Leddy Phelan, The Hispanization of the Philippines. Wisconsin, University of Wisconsin Press, 1959, pp. 4-8; Onofre D.Corpuz The Roots of the Filipino Nation, Vol. 1. Quezon City, AKLAHI Foundation, Inc., 1989, p. 46). In late 1960s, the MNLF reincarnated the pre-colonial Sultanates of Mindanao and Sulu as "Bangsa Moro," independent and sovereign, that must be re-claimed from the Philippine state through an armed struggle.

29. "The Moro Struggle for Self-Determination and the Moro Islamic Liberation Front." Available from:

http://www.db.idpproject.org/Sites/IdpProjectDb/idpSurvey.nsf/AllDocWeb/4F62C40 ACE5A0370C12568F70058401C/\$file/MILF_self-determination.PDF. (Accessed on 02 November 2003).

30. "Bangsamoro Muslims' determination to establish an Islamic State, "Crescent International, 16-31 March 1999.

31. "Murad extends greetings of peace and solidarity to Muslim believers", 10 November 2003 News. Available from: <http://www.luwaran.com/> (Accessed on 29 October 2003).

32. Ibid.

33. Daniel Philpott, "In Defense of Self-Determination”, Ethics, 105, 1995, pp. 352-385).

34. Carolyn O. Arguillas, "Gov't's offer to the MILF: Expanded, strengthened, autonomy: amnesty, demobilization, assistance," MindaNews, 3 June 2003. Available from: <http://www.mindanews.com/2003/06/03pep-draft.html>. (Accessed on 29 October 2003).

35. "MILF peace negotiator: Autonomy option, "tired phrase", 29 November 2003 News. Available from: <http://www.luwaran.com/>. (Accessed on 29 October 2003).

36. Ibid.

37. Quickstat on Autonomous Region in Muslim Mindanao, June 2000. Available from: $<$ http://www.census.gov.ph/data/quickstat/qs150006.html>. (Accessed on 15 November 2003).

38. The 1998 Annual Poverty Indicators Survey Results. Available from: $<$ http://www.census.gov.ph/data/sectordata/dataapis.html>. (Accessed on 15 November 2003).

39. Romy Elusfa, "Is there hope for a GRP-MILF peace pact?" MindaNews, 12 December 2002. 
40. The doctrine that affirms the ultimate right of the State to own lands and resources under its political jurisdiction. Sec. 2, Art. 12 of the 1987 Constitution provides: "All lands of the public domain, waters, minerals, coal, petroleum, and other mineral oils, all forces of potential energy, fisheries, forests or timber, wildlife, flora and fauna, and other natural resources are owned by the State... The exploration, development and utilization of natural resources shall be under the full control and supervision of the State... (italics provided).

41. Fernando Poe Jr. is known as the King of Philippine Movies and a close friend of former President Joseph Estrada. He is one of the most popular movie actors in the country for his portrayal of heroic roles in movies - as enemy of the rich and powerful who exploit and oppress the masses. The poor masses tend to identify their miserable plight, aspirations, and ideals with Poe who considers himself their liberator. In most opinion surveys conducted by respectable research outfits, Poe has consistently made it to the top as the people's choice for the next President. 